\title{
Brazilian red pepper fruit essential oil (Schinus terebinthifolius) may replace monensin in high concentrate diets for feedlot lambs
}

\author{
Óleo essencial dos frutos de aroeira (Schinus terebinthifolius) pode \\ substituir a monensina em dietas com elevado teor de concentrado para \\ cordeiros confinados
}

\begin{abstract}
Analisa Vasques Bertoloni ${ }^{1}$; Daniel Montanher Polizel1,2* (D); Marcos Vinícius de Castro Ferraz Júnior ${ }^{3 ;}$ Alexandre Arantes Miszura ${ }^{1}$; José Paulo Roman Barroso ${ }^{1}$; André Storti Martins ${ }^{1}$; Lairana Aline Sardinha ${ }^{1}$; Arnaldo Cintra Limede ${ }^{1}$; Gabriela Bagio Oliveira ${ }^{1}$; Evandro Maia Ferreira ${ }^{2}$; Alexandre Vaz Pires ${ }^{1,2}$

\footnotetext{
${ }^{1}$ Universidade de São Paulo, Faculdade de Medicina Veterinária e Zootecnia, Departamento de Nutrição e Produção Animal, Pirassununga - SP, Brasil ${ }^{2}$ Universidade de São Paulo, Escola Superior de Agricultura "Luiz de Queiroz”, Departamento de Zootecnia, Piracicaba - SP, Brasil ${ }^{3}$ Universidade Federal do Amazonas, Instituto de Ciências Sociais, Educação e Zootecnia, Parintins - AM, Brasil
}

\begin{abstract}
Essential oil (EO) from Brazilian red pepper fruit contains compounds with antimicrobial activity, and could be possible substitutes for the antibiotics commonly used in ruminant nutrition. The objectives of the present study were to evaluate the effects of the Brazilian red pepper fruit $\mathrm{EO}$ (Schinus terebinthifolius) as a substitute for monensin on performance, carcass characteristics and meat of lambs fed high concentrate diets. Forty-eight lambs were used, 24 males ( 20 1/2 Dorper $\times 1 / 2$ Santa Inês and 4 Santa Inês) and 24 females ( $241 / 2$ Dorper $\times 1 / 2$ Santa Inês), with $21.54 \pm 0.88 \mathrm{~kg}$ of initial body weight (BW) and $78 \pm 2.4$ days of age, in a randomized complete block design. The experiment lasted 56 days, divided into 2 periods of 28 days each. The treatments were defined by the inclusion in diets of $8 \mathrm{ppm}$ of monensin (MON), and the doses $0.14 \%(14 \mathrm{EO}), 0.28 \%(28 \mathrm{EO})$ and $0.42 \%$ (42EO) of red pepper fruit EO. The additives were included in a base diet with a 10:90 of forage to concentrate ratio. At the end of 56 days, 32 animals were slaughtered for the measurement of carcass parameters and meat composition. There was no interaction among treatments and periods for average daily gain $(P=0.08)$, DM intake $(P=0.36)$, feed efficiency $(\mathrm{P}=0.24)$ and oocyst of Eimeria ssp. in feces $(\mathrm{P}=0.46)$. The treatments did not affect $(\mathrm{P}>0.05)$ the average daily gain (ADG), dry matter intake (DMI) and feed efficiency. Lambs fed diets containing monensin had less $(\mathrm{P}<0.01)$ oocyst $/ \mathrm{g}$ compared with the diet 14EO. There was no effect of diets on carcass characteristics. The treatments with higher doses of the Brazilian red pepper fruit EO had reduced mineral content of meat compared to monensin. The red pepper fruit EO demonstrated the potential to replace monensin in feedlot lambs fed high concentrate diets, maintaining performance and carcass characteristics. However, the monensin has greater capacity to control coccidiosis in feedlot lambs.
\end{abstract}

Keywords: Additive. Vegetal extracts. Performance. Carcass characteristic.

\section{RESUMO}

Os óleos essenciais (OE) dos frutos de aroeira possuem compostos com atividade antimicrobiana, sendo possíveis substitutos aos antibióticos comumente utilizados na nutrição de ruminantes. Os objetivos do presente estudo foram avaliar os efeitos da inclusão do óleo essencial de aroeira fruta (Schinus terebinthifolius) como substituto da monensina sobre o desempenho, características de carcaça e da carne de cordeiros alimentados com dietas contendo elevado teor de concentrado. Foram utilizados 48 cordeiros, 24 machos (20 1/2 Dorper $\times 1 / 2$ Santa Inês e 4 Santa Inês) e 24 fêmeas ( 24 1/2 Dorper $\times 1 / 2$ Santa Inês), com peso inicial de 21,54 $\pm 0,88 \mathrm{~kg}$ e $78 \pm 2,4$ dias de idade, em delineamento de blocos completos casualizados. O experimento teve duração de 56 dias, divididos em 2 períodos de 28 dias cada. Os tratamentos foram definidos pela inclusão na dieta de $8 \mathrm{ppm}$ de monensina sódica (MON) e as doses de 0,14\% (14EO), 0,28\% (28EO) e $0,42 \%$ (42EO) de óleo essencial dos frutos da aroeira. As dietas experimentais foram compostas por 10\% de volumoso e $90 \%$ de concentrado. Ao final dos 56 dias, 32 animais foram abatidos para a mensuração dos parâmetros de carcaça e análise química da carne. Não houve interação entre tratamento e período para o ganho médio diário $(\mathrm{P}=0,08)$, consumo de MS $(\mathrm{P}=0,36)$, eficiência alimentar $(\mathrm{P}=0,24)$ e contagem de oocistos de Eimeria ssp. $(\mathrm{P}=0,46)$. Não houve efeito $(\mathrm{P}>0,05)$ dos tratamentos no ganho de peso médio diário (GMD), consumo de matéria seca (CMS) e eficiência alimentar (EA). Cordeiros alimentados com dietas contendo monensina tiveram menor $(\mathrm{P}<0,01)$ contagem de oocistos/g de fezes comparado com a dieta 14OE. Não houve efeito das dietas sobre as características de carcaça. 
A inclusão de 0,28 e $0,42 \%$ de OE de aroeira fruto reduziram a concentração de matéria mineral da carne dos cordeiros comparados ao tratamento MON. O OE dos frutos da aroeira demonstrou capacidade de substituir a monensina, apresentando resultados similares com relação ao desempenho e características de carcaça. Entretanto, a monensina apresentou maior capacidade no controle de coccidiose.

Palavras-chave: Aditivos. Extratos vegetais. Desempenho. Características de carcaça.

\section{Correspondence to:}

Daniel Montanher Polizel

Universidade de São Paulo, Escola Superior de Agricultura

"Luiz de Queiroz", Departamento de Zootecnia

Avenida Pádua Dias, 11, Bairro Agronomia.

CEP: 13418-900, Piracicaba - SP, Brasil

e-mail:dmpolizel@gmail.com

Received: January 01, 2019

Approved: May 17, 2019
How to cite: Bertoloni AV, Polizel DM, Ferraz Júnior MVC, Miszura AA, Barroso JPR, Martins AS, Sardinha LA, Limede AC, Oliveira GB; Ferreira EM, Pires AV. Brazilian red pepper fruit essential oil (Schinus terebinthifolius) may replace monensin in high concentrate diets for feedlot lambs. Braz J Vet Res Anim Sci. 2019;56(3):e153845. https://doi.org/10.11606/issn.1678-4456.bjvras.2019.153845

\section{Introduction}

The adequacy of diets for the nutritional requirements of food-production animals and the use of feed additives that modify the ruminal environment are common methods used to increase energy retention (Perna et al., 2017) and protein utilization by ruminants (Del Valle et al., 2017). The most used feed additives in animal nutrition are ionophores antibiotics, non-ionophores antibiotics and probiotics (Nicodemo, 2001).

In recent years, public concern about the continued use of antibiotics in animal nutrition has increased due to the possible emergence of pathogenic microorganisms resistant to antibiotics or to active principles, which may present a risk to human health (Benchaar et al., 2006). In this context, there has been increased interest in evaluating alternatives to modulate ruminal fermentation, including the use of organic acids, plant extracts and antibodies (Calsamiglia et al., 2006). The essential oils (EO) may be an alternative feed additive in ruminant nutrition since they have antimicrobial, antifungal, antiviral, antiparasitic, insecticidal, antiprotozoal and antioxidant effects (Cowan, 1999).

Volatile chemical compounds present in $\mathrm{EO}$ are limonene, $\alpha$-pinene, $\beta$-carophylenne, $\mathrm{p}$-cymene, $\alpha$-humulene, and others (Burt, 2004). The Brazilian red pepper (Schinus terebinthifolius Raddi, Anacardiaceae) exhibits antifungal properties (Johann et al., 2010), antimicrobial activity (Lima et al., 2006) and the ability to change fermentative parameters in vitro and in vivo, having the a-pinene as the main constituent (Araújo, 2010; Faleiro Neto, 2015).

Therefore, it has been hypothesized that Brazilian red pepper fruit EO could replace the monensin in feedlot lambs as a feed additive. The objectives of the present study were to evaluate the effects of Brazilian red pepper fruit $\mathrm{EO}$ as a substitute for monensin on performance, occurrence of coccidiosis by Eimeria ssp., carcass characteristics and meat of lambs fed high concentrate diets.

\section{Materials and Methods}

Forty-eight lambs were used, 24 males (20 1/2 Dorper $\times$ $1 / 2$ Santa Inês and 4 Santa Inês) and 24 females ( 24 1/2 Dorper $\times 1 / 2$ Santa Inês), with $21.54 \pm 0.88 \mathrm{~kg}$ of initial body weight (BW) and $78 \pm 2.4$ days of age.

The experiment consisted of a $56-\mathrm{d}$ period, divided into two 28 -d periods. The animals were weighed after $14 \mathrm{~h}$ of solid fasting period on $\mathrm{d} 0,28$ and 56 of the trial period. The experiment design used was randomized complete block. Each block was defined by sex, breed and initial BW. The lambs were kept indoors, in an individual tie-stall system, with a slatted floor, feed bunk, and waterer. On $\mathrm{d} 28$ and 56, feces samples were collected to evaluate the coccidiosis oocyst Eimeria ssp. (COC), using the method described by Gordon \& Whitlock (1939).

The red pepper fruit EO composition was performed by gas chromatography coupled to mass spectrometry provided with an automatic injector, using a capillary column with a 30 meters length and $25 \mathrm{~mm}$ internal diameter. The total chromatographic run time was $60 \mathrm{~min}$, divided into five heating cycles, as follows: $50^{\circ} \mathrm{C}(30 \mathrm{~min})$, $200^{\circ} \mathrm{C}\left(4^{\circ} \mathrm{C} / \mathrm{min}\right), 240^{\circ} \mathrm{C}\left(10^{\circ} \mathrm{C} / \mathrm{min}\right), 280^{\circ} \mathrm{C}\left(10^{\circ} \mathrm{C} / \mathrm{min}\right)$, and $290^{\circ} \mathrm{C}\left(5^{\circ} \mathrm{C} / \mathrm{min}\right)$.

The experimental diets were defined by the addition of monensin (Rumensin 200, Elanco Animal Health, São Paulo, SP, Brazil), or doses of red pepper fruit EO (Lazlo Aromaterapia, Belo Horizonte, MG, Brazil). The experimental diets were as follows: inclusion of $8 \mathrm{mg}$ of monensin $/ \mathrm{kg}$ of DM (M); diets with $0.14 \%$ (14EO), $0.28 \%$ (28EO) and $0.42 \%$ of red pepper fruit $\mathrm{EO}(42 \mathrm{EO})$. The additives were included in a basal diet with a 10:90 of forage to concentrate ratio (Table 1). The experimental diets were formulated 
Table 1 - Proportion of the ingredients and chemical composition of the experimental diets containing monensin or red pepper fruit EO (Piracicaba, 2019)

\begin{tabular}{|c|c|c|c|c|}
\hline \multirow{2}{*}{ Item } & \multicolumn{4}{|c|}{ Diets $^{1}$} \\
\hline & MON & 14EO & 28EO & 42EO \\
\hline \multicolumn{5}{|l|}{ Ingredient, \% DM } \\
\hline Coastcross hay & 10.00 & 10.00 & 10.00 & 10.00 \\
\hline Ground corn & 72.00 & 71.86 & 71.72 & 71.58 \\
\hline Soybean meal & 14.00 & 14.00 & 14.00 & 14.00 \\
\hline Urea & 0.50 & 0.50 & 0.50 & 0.50 \\
\hline Mineral premix & 1.50 & 1.50 & 1.50 & 1.50 \\
\hline Ammonium chloride & 0.50 & 0.50 & 0.50 & 0.50 \\
\hline Limestone & 1.50 & 1.50 & 1.50 & 1.50 \\
\hline Red pepper fruit EO & 0.00 & 0.14 & 0.28 & 0.42 \\
\hline Monensin, ppm & 8.00 & 0.00 & 0.00 & 0.00 \\
\hline \multicolumn{5}{|l|}{ Chemical composition ${ }^{2}$} \\
\hline DM, as-fed basis & 88.19 & 87.93 & 87.92 & 87.82 \\
\hline Ash & 6.33 & 6.49 & 6.24 & 6.53 \\
\hline $\mathrm{CP}$ & 19.02 & 19.26 & 19.32 & 19.25 \\
\hline NDF & 18.10 & 18.39 & 18.17 & 18.75 \\
\hline ADF & 7.03 & 6.97 & 6.93 & 7.15 \\
\hline EE & 4.26 & 4.30 & 4.32 & 4.31 \\
\hline NFC & 52.29 & 51.56 & 51.95 & 51.16 \\
\hline $\mathrm{TDN}^{3}$ & 80.60 & 78.15 & 79.49 & 79.46 \\
\hline
\end{tabular}

${ }^{1} \mathrm{MON}$ : diet containing $8 \mathrm{mg}$ of monensin/kg of DM; 14EO: inclusion of $0.14 \%$ of red pepper fruit EO (DM basis); $28 \mathrm{EO}$ : inclusion of $0.28 \%$ of red pepper fruit EO; 42EO: inclusion of $0.42 \%$ of red pepper fruit EO. ${ }^{2} \mathrm{DM}$ : dry matter; CP: crude protein; NDF: neutral detergent fiber; ADF: acid detergent fiber; EE: Ether extract; NFC: non-fiber carbohydrate; ${ }^{3} \mathrm{TDN}$ : total digestible nutrient (Weiss et al., 1992).

according to National Research Council (National Research Council, 2007).

The total mixed diets were offered once a day at 08:00 a.m. and animals were allowed ad libitum access to feed. The experimental diets were prepared weekly to avoid possible changes in the compounds present in the EO and, at each mixture, a sample was collected and stored at $-18^{\circ} \mathrm{C}$ for further analysis. Orts were recorded daily to determine the dry matter intake (DMI), and the refused feed did not exceed $5 \%$ of daily offer. In each experimental period (28d), average daily gain (ADG) and feed efficiency (FE) were calculated.

The DM and ash content were determined according to Association of the Official Analytical Chemists (1990). Sequential detergent fiber analyses were determined according to Van Soest et al. (1991) using an Ankon 2000 fiber analyzer (Ankom Tech. Corp., Fairport, NY, USA). Total N was determined using the Leco TruMac N (Leco Corp., St. Joseph, MI, USA) according to the Association of the Official Analytical Chemists (1990). The ether extract of the diets was determined according to the Association of the Official Analytical Chemists (1990). Non-fiber carbohydrates of the diets were estimated according to the following equation: NFC $(\%)=100 \%-(\% \mathrm{NDF}+\% \mathrm{CP}+\%$ fat $+\%$ ash $)$. The total digestible nutrient (TDN) content was calculated according to Weiss et al. (1992).

At the end of the 56 days, 32 lambs (16 male and 16 female) were slaughtered, following the norms described in the Regulation of the Industrial and Sanitary Inspection of Products of Animal Origin - RIISPOA. The lambs were weighed after $14 \mathrm{~h}$ fasting period to obtain the slaughter weight (SW). Carcass characteristics evaluated were hot carcass weight (HCW) and hot carcass yield (HCY), obtained at the time of slaughter. After $24 \mathrm{~h}$ of chilling $\left(4^{\circ} \mathrm{C}\right)$, the chilled carcass weight (CCW), chilled carcass yield (CCY), subcutaneous fat thickness over the $12^{\text {th }}$ rib (SFT), body wall thickness (BWT), and Longissimus muscle area (LM area) were obtained. Approximately $15 \mathrm{~cm}$ samples of the Longissimus dorsi muscle from the right half carcass of each animal were collected and stored at $-18^{\circ} \mathrm{C}$ for further determination of the chemical composition of the meat. The DM, ash, total $\mathrm{N}$ and ether extract content of the Longissimus dorsi meat were determined according to Association of the Official Analytical Chemists (1990).

Statistical analyses were performed using the MIXED procedure of the SAS (SAS version 9.0; SAS Inst. Inc., Cary, NC, USA). All data were submitted to the Levene test to verify the homogeneity of variances, the Shapiro-Wilk test to check the normality of the residuals and the removal of "outliers". The animals were considered as the experimental unit to perform statistical analyses. The treatment means were obtained by the LSMEANS command. The treatment effect was defined by Tukey test. The period effect and treatment $x$ period interaction were defined by the $F$ test of ANOVA. Statistical significance was declared at $\mathrm{P} \leq 0.05$, with trends noted at $\mathrm{P}>0.05$ to $\mathrm{P}<0.10$. 


\section{Results}

The main components found in the red pepper fruit $\mathrm{EO}$ used in the present study were $\alpha$-pinene (40.4\%), $\alpha$-limonene (13.1\%), $\Delta$-3-carene (8.3\%), $\beta$-pinene (7.0\%), $p$-cymene (7.0\%), myrcene (5.6\%), $\alpha$-phellandrene (3.5\%). In addition, the compounds sabinene, $\Delta$-cadinene, $\beta$-phellandrene, $\beta$-caryophyllene, germacrene $D$, terpinen-4-ol, $\alpha$-copaene, $\alpha$-terpinolene, $\delta$-terpinene, camphene and $\alpha$-terpinene were identified in the red pepper fruit $\mathrm{EO}$ in concentrations less than $2.5 \%$.

There was no interaction among treatments and period for ADG, DMI, FE and COC (Table 2). In addition, the treatments did not affect the lambs' performance. Lambs fed diets containing monensin had less $(\mathrm{P}<0.01)$ oocyst/g compared with $14 \mathrm{EO}$, while the $28 \mathrm{EO}$ and $42 \mathrm{EO}$ treatments presented intermediate values.

There was period effect for ADG $(\mathrm{P}<0.01)$, DMI $(\mathrm{P}<0.01)$, FE $(\mathrm{P}<0.01)$ and COC $(\mathrm{P}<0.01)$. The DMI increased (P1: $904.37 \pm 42.13$; P2: $1077.88 \pm 42.13 \mathrm{~g} /$ day) and ADG decreased (P1: $278.8 \pm 18.81$; and P2: $258.9 \pm 18.81 \mathrm{~g} /$ day $)$ during the experimental periods; consequently, the FE was greater in the first period compared with second (P1: $0.30 \pm 0.01 ; \mathrm{P} 2: 0.23 \pm 0.01)$. The oocyst count increased between the periods (P1: $1.50 \pm 0.42$; and P2:3.44 \pm 0.66 oocysts/g).

The treatments did not affect the carcass characteristic (Table 3). In addition, there was no effect on DM, CP and EE in Longissimus dorsi meat. However, lambs fed diets containing monensin had a greater ash content in lamb meat when compared with $28 \mathrm{EO}$ and $42 \mathrm{EO}$.

Table 2 - Performance and oocyst counts of feedlot lambs fed high-concentrate diets containing monensin or red pepper fruit EO. (Piracicaba, 2019)

\begin{tabular}{|c|c|c|c|c|c|c|c|c|}
\hline \multirow{2}{*}{ Item ${ }^{4}$} & \multicolumn{4}{|c|}{ Diets $^{1}$} & \multirow{2}{*}{ SEM $^{2}$} & \multicolumn{3}{|c|}{ P-value ${ }^{3}$} \\
\hline & MON & $14 \mathrm{EO}$ & $28 E O$ & 42EO & & Diets & $\mathbf{P}$ & $\mathbf{D} \times \mathbf{P}$ \\
\hline \multicolumn{9}{|l|}{ BW, kg } \\
\hline Initial & 21.66 & 21.28 & 21.71 & 21.49 & 0.88 & 0.88 & - & - \\
\hline $28 d$ & 29.47 & 29.22 & 29.59 & 29.49 & 1.15 & 0.97 & - & - \\
\hline $56 d$ & 36.67 & 36.97 & 35.16 & 35.72 & 1.58 & 0.40 & - & - \\
\hline$A D G, g$ & 273.51 & 271.06 & 260.86 & 269.94 & 22.96 & 0.95 & 0.02 & 0.08 \\
\hline DMI, g/dia & 1018.86 & 988.03 & 987.25 & 970.36 & 46.63 & 0.59 & $<0.01$ & 0.36 \\
\hline FE, gain:feed & 0.268 & 0.274 & 0.264 & 0.278 & 0.02 & 0.88 & $<0.01$ & 0.24 \\
\hline Oocyst/g & $0.92^{\mathrm{b}}$ & $4.73^{a}$ & $2.30^{\mathrm{ab}}$ & $2.17^{\mathrm{ab}}$ & 0.86 & 0.02 & $<0.01$ & 0.46 \\
\hline
\end{tabular}

${ }^{1} \mathrm{MON}$ : diet containing $8 \mathrm{mg}$ of monensin $/ \mathrm{kg}$ of DM; $14 \mathrm{EO}$ : inclusion of $0.14 \%$ of red pepper fruit EO (DM basis); $28 \mathrm{EO}$ : inclusion of $0.28 \%$ of red pepper fruit EO; 42EO: inclusion of $0.42 \%$ of red pepper fruit EO. ${ }^{2} \mathrm{SEM}$ : standard error of the means; ${ }^{3} \mathrm{P}$ : period effect; D $\times$ P: diets and periods interaction; ${ }^{4} \mathrm{ADG}$ : average daily gain; DMI: dry matter intake; FE: feed efficiency. ${ }^{\mathrm{a}-\mathrm{b}}$ means in the same row with different superscripts differ $(\mathrm{P} \leq 0.05)$. ${ }^{\mathrm{A}-\mathrm{B}}$ means in the same row with different superscripts tented to differ $(\mathrm{P}>0.05$ to $\mathrm{P}<0.10)$.

Table 3 - Carcass characteristics and meat composition of feedlot lambs fed high-concentrate diets containing monensin or red pepper fruit EO. (Piracicaba, 2019)

\begin{tabular}{|c|c|c|c|c|c|c|}
\hline \multirow{2}{*}{ Item $^{3}$} & \multicolumn{4}{|c|}{ Diets $^{1}$} & \multirow{2}{*}{ SEM $^{2}$} & \multirow{2}{*}{ P-value } \\
\hline & MON & 14EO & 28EO & 42EO & & \\
\hline Slaughter weight, kg & 38.80 & 36.85 & 38.02 & 37.84 & 1.94 & 0.76 \\
\hline \multicolumn{7}{|l|}{ Carcass characteristics } \\
\hline $\mathrm{HCW}, \mathrm{kg}$ & 19.30 & 18.87 & 18.67 & 18.64 & 0.97 & 0.84 \\
\hline $\mathrm{HCY}, \%$ & 49.77 & 51.48 & 49.03 & 49.50 & 0.80 & 0.90 \\
\hline $\mathrm{CCW}, \mathrm{kg}$ & 18.77 & 18.31 & 18.12 & 18.12 & 0.95 & 0.82 \\
\hline $\mathrm{CCY}, \%$ & 48.41 & 49.69 & 47.66 & 48.05 & 0.79 & 0.88 \\
\hline BWT, mm & 12.48 & 13.78 & 13.35 & 14.41 & 1.06 & 0.60 \\
\hline $\mathrm{SFT}, \mathrm{mm}$ & 1.71 & 1.64 & 1.52 & 1.65 & 0.21 & 0.78 \\
\hline LM area, $\mathrm{cm}^{2}$ & 13.40 & 13.93 & 13.69 & 12.80 & 0.79 & 0.67 \\
\hline \multicolumn{7}{|l|}{ Meat composition, \% } \\
\hline $\mathrm{DM}$ & 25.71 & 25.80 & 25.59 & 25.65 & 0.23 & 0.91 \\
\hline $\mathrm{CP}$ & 23.64 & 23.60 & 23.60 & 23.42 & 0.24 & 0.90 \\
\hline Ash & $1.31^{a}$ & $1.30^{\mathrm{ab}}$ & $1.23^{c}$ & $1.24^{b c}$ & 0.02 & $<0.01$ \\
\hline EE & 2.26 & 2.13 & 2.36 & 2.47 & 0.19 & 0.63 \\
\hline
\end{tabular}

${ }^{1} \mathrm{MON}$ : diet containing $8 \mathrm{mg}$ of monensin/kg of DM; 14EO: inclusion of $0.14 \%$ of red pepper fruit EO (DM basis); $28 \mathrm{EO}$ : inclusion of $0.28 \%$ of red pepper fruit EO; 42EO: inclusion of $0.42 \%$ of red pepper fruit EO. ${ }^{2} \mathrm{SEM}$ : standard error of the means. ${ }^{3} \mathrm{HCW}$ : hot carcass weight; HCY: hot carcass yield; CCW: chilled carcass weight; CCY: chilled carcass yield; BWT: body wall thickness; SFT: subcutaneous fat thickness; LM area: Longissimus muscle area; DM: dry matter; $\mathrm{CP}$ : crude protein; EE: ether extract. ${ }^{\mathrm{a}-\mathrm{b}}$ means in the same row with different superscripts differ $(\mathrm{P} \leq 0.05)$. ${ }^{\mathrm{A}-\mathrm{B}}$ means in the same row with different superscripts tented to differ $(\mathrm{P}>0.05$ to $\mathrm{P}<0.10)$. 


\section{Discussion}

Similar results observed in this study have been reported in other studies with different EOs sources (Anassori et al., 2011; Anassori et al., 2017). As for ionophores, the major effects of plant extracts on the ruminant metabolism were related to modulation of rumen fermentation. The limonene and pinene were able to inhibit methane production by altering the fermentation process (Cattani et al., 2016; Cobellis et al., 2016). Essential oils can also increase dietary energy efficiency and concentration of ruminal propionate, besides reducing the ruminal deamination (McIntosh et al., 2003).

Araújo (2010) conducted an in vitro study evaluating the use of essential oils from plants native to Brazil with potential for manipulation of ruminal fermentation and found that the red pepper (leaves and fruit) and lemon grass EO inclusion resulted in greater energy efficiency during the fermentation process. Additionally, the author observed that the inclusion of Brazilian red pepper EO increased the propionate concentration, reduced the acetate:propionate ratio and decreased methane production.

The extraction method may influence the chemical composition of the EO (Burt, 2007). The environment in which the plant develops and the type of crop can also cause variations in composition (Dorman \& Deans, 2000). In this study, the compounds with the highest concentration were $\alpha$-pinene and $\alpha$-limonene. However, authors who also used red pepper fruit EO founded differences in the chemical composition of EO. Araújo (2010) related that $\alpha$-pinene (25.0\%), $\Delta$-3-carene (22.4\%), $\alpha$-felandren (18.5\%), silvestrene (15.9\%) and p-cymene (11.0\%), were the main components found in the red pepper fruit EO, whereas Faleiro Neto (2015) reported $\alpha$-pinene (21.4\%), silvestrene (18.2\%), $\Delta$-3-carene (17.4\%), p-cymene (16.2\%) and $\alpha$-felandren (15.1\%) as main components. This variation can be attributed to the issue intrinsic to the material used for the extraction of EO, since the technique of extraction and analysis of composites was the same in all the experiments described. However, in all experiments, the main compound identified in red pepper fruit $\mathrm{OE}$ was the $\alpha$-pinene.

It is important to emphasize that some EO may decrease the ration acceptability reducing DMI (Calsamiglia et al., 2007). Estell et al. (1998) consider that the inclusion of high doses of a-pinene may decrease DMI. In addition, of the 23 volatile compounds examined, only four were related to intake when tested individually, camphor, a-pinene, camphene, and caryophyllene oxide (Estell et al., 2008). However, although red pepper fruit EO presented a characteristic and marked odor, the doses used in the present study did not affect DMI when compared to the diet containing monensin.

In previous studies, the $\alpha$-pinene was the main compound that has shown positive results in animal performance (Silva et al., 2010). In a study with juniper oil (Juniperus communis), which contained 35\% a-pinene, an increase of $17 \%$ on ADG in lambs was observed (Chaves et al., 2008) although it did not change the molar ratio and the total concentration of short chain fatty acids (SCFA). In addition, the essential oils containing pinene increased the feed efficiency of finishing steers (Meyer et al., 2009). In the present study, the increased doses of Brazilian red pepper fruit EO did not affect the ADG and FE compared with monensin.

The lambs presented higher ADG in the first period of the experiment. This is due to the allometric characteristics causing the tissues to have different growth rates, which change in distinct phases of the animals' life (Petrovic et al., 2015). As the animal reaches physiological maturity, muscle growth decreases and fat tissue deposition increases, leading to lower weight gain. Furthermore, there is an increase in DMI so the animal can meet higher nutritional requirements. Thus, the ADG, DMI and FE are also affected by the growth stages of the animal.

Although it is of great importance, the studies that evaluate the use of $\mathrm{EO}$ in the performance of ruminants do not evaluate the data on the contamination by Eimeria ssp., which can be controlled with the addition of antibiotics such as monensin in the diet (Amarante, 2015). In this experiment, the animals that received MON treatment presented lower infestation by Eimeria ssp., when compared to the animals that received red pepper fruit EO. Calhoun et al. (1979) performed an experiment using four doses of monensin $(5.5,11,22$ and $33 \mathrm{mg} / \mathrm{kg})$ in diet of lambs, and observed monensin decreased the number of coccidian oocysts at all fed levels, demonstrating that even the dose of $5.5 \mathrm{mg} / \mathrm{kg}$ monensin was effective in the control of coccidiosis. Among the diets containing red pepper fruit EO, the lambs that received the $14 \mathrm{EO}$ diet showed a greater number of oocysts, inferring that low doses of EO may be ineffective against coccidiosis. In addition, the infestation by the animals was higher in the second period of the experiment. According to Amarante (2015), the multiplication of parasites in the host may cause clinical coccidiosis; however, this was not observed in the present study.

The lack of effect on carcass characteristics can be justified by the similar performance among treatments during the experimental period, which caused the same slaughter weight among treatments. The slaughter weight 
of lambs in the present study was higher than the slaughter weight commonly observed in the Brazilian market, which normally ranges from 28 to $35 \mathrm{~kg}$ of BW. This weight range avoids unsatisfactory conditions of muscular development and finishing, allied with the slaughter of young lambs (Müller, 1991). However, the lamb intensive system allows the slaughter of lambs less than 5 months old and weighing more than $40 \mathrm{~kg}$.

According to Osório \& Osório (2001), in order to avoid shortening of muscle fibers by exposure to cold, there is an adequate fat thickness that the carcasses must reach. The percentage of fat in the carcass is usually affected by age, genotype, sex, breed, nutrition and feeding time. In the present study, the mean fat thickness was $1.63 \mathrm{~mm}$, which was similar to Cartaxo et al. (2017) that reported SFT values for crossbreed Dorper $\times$ Santa Inês lambs with a mean of $1.25 \mathrm{~mm}$, whereas $3 / 4$ Dorper $\times 1 / 4$ Santa Inês lambs had SFT $27 \%$ higher than the $1 / 2$ Dorper $\times 1 / 2$ Santa Inês animals. However, these values were lower in relation to the recommendation of 2.0 to 5.0 proposed by Osório \& Osório (2001). The protein content of the diet may also influence fat deposition in the carcass, since the protein levels ingested by the animals may change the proportion of fat in the carcass.

The centesimal composition of meat can be influenced by several aspects such as puberty, breed, age and weight at slaughter, nutrition, management strategy and others (Guerrero et al., 2013). According to Spears (1990), numerous studies indicate that ionophores affect the apparent absorption of minerals, but mechanisms by which ionophores influence mineral absorption have not been elucidated. Significant increases in magnesium absorption were observed in steers and lambs fed high-concentrate diets with ionophores (Starnes et al., 1984; Greene et al., 1988). The apparent absorption of phosphorus, calcium (Spears et al., 1989) and potassium was increased by the monensin (Kirk et al., 1985; Greene et al., 1988; Spears et al.,

\section{References}

AOAC: Association of the Official Analytical Chemists. Official Methods of Analysis. 15th ed. Arlington: AOAC International; 1990.

Amarante AFT. The parasites of sheep. 1. ed. São Paulo: Editor Unesp Digital; 2015. Chapter 5, Eimeriose; p. 139-45.

Anassori E, Dalir-Naghadeh B, Pirmohammadi R, Taghizadeh A, Asri-Rezaei S, Maham M, Farahmand-Azar S, Farhoomand
1989). Starnes et al. (1984) reported that monensin increased apparent sodium uptake in steers fed a high-concentrate diet. Compared to the animals that received the control diet, lambs fed monensin showed greater apparent absorption of phosphorus, magnesium and potassium (Droke et al., 1989). This increase in minerals absorption caused by the inclusion of monensin in the diets may explain the increase in the ash content in the meat of lambs fed with the ionophore. In addition, the $14 \mathrm{EO}$ presented similar values to MON, suggesting that the inclusion of low doses of Brazilian red pepper fruit EO may change the mineral metabolism in the feedlot lambs.

\section{Conclusion}

The Brazilian red pepper fruit EO can be included in high concentrate diets in feedlot lambs, since they presented performance and carcass characteristics similar to animals fed with MON. However, it is important to consider whether the environment has high contamination of coccidia, since monensin was more efficient in controlling the number of oocysts in the feces. As a suggestion for new research, it is necessary to study the efficiency of use of red pepper fruit essential oil for feedlot lambs in relation to diets without additives.

\section{Conflict of Interest}

We have no conflict of interest to declare.

\section{Ethics Statement}

The ethics committee approval certificate is attached (CEUA n 5468211016).

\section{Acknowledgements}

The authors thank for Coordination of Improvement of Higher Education Personnel (CAPES) for a scholarship to Analisa Vasques Bertoloni.

P. Garlic: A potential alternative for monensin as a rumen modifier. Livest Sci. 2011;142(1-3):276-87. https://doi. org/10.1016/j.livsci.2011.08.003.

Anassori E, Dalir-Naghadeh B, Valizadeh-Kesmeshtappeh $\mathrm{M}$, Jafari S. A comparative study on the efficacy of Garlicon and monensin supplementation on blood metabolites and performance of fattening lambs. Livest Sci. 2017;199:74-8. http://dx.doi.org/10.1016/j.livsci.2017.03.014. 
Araújo RC. Essential oils from Brazilian plants as in vitro rumen fermentation modifiers [thesis]. São Paulo: Escola Superior de Agricultura "Luiz de Queiroz", University of São Paulo; 2010. 178 p.

Benchaar C, Duynisveld JL, Charmley E. Effects of monensin and increasing dose levels of a mixture of essential oil compounds on intake, digestion and growth performance of beef cattle. Can J Anim Sci. 2006;86(1):91-6.

Burt S. Essential oils: their antibacterial properties and potential applications in foods-a review. Int J Food Microbiol. 2004;94(3):223-53. http://dx.doi.org/10.1016/j. ijfoodmicro.2004.03.022. PMid:15246235.

Burt SA. Antibacterial activity of essential oils: potential applications in food. [thesis]. Netherlands: Utrecht University; 2007. 135 p.

Calhoun MC, Carroll LH, Livingston CW Jr, Shelton M. Effect dietary monensin on coccidial oocyst numbers, feedlot performance and carcass characteristics of lambs. J Anim Sci. 1979;49(1):10-9. http://dx.doi.org/10.2527/jas1979.49110x.

Calsamiglia S, Busquet M, Cardozo PW, Castillejos L, Ferret A. Invited review: essential oils as modifiers of rumen microbial fermentation. J Dairy Sci. 2007;90(6):2580-95. http://dx.doi. org/10.3168/jds.2006-644. PMid:17517698.

Calsamiglia S, Caltillejos L, Busquet M. Alternatives to antimicrobial growth promoters in cattle. In: Garnsworthy PC, Wiseman J, editors. Recent Advances in Animal Nutrition. University Press Nottingham, Nottingham, p. 129-67, 2006.

Cartaxo FQ, Sousa WH, Cezar MF, Cunha MGG, Menezes LM, Ramos JPF, Gomes JT, Viana JA. Performance and carcass traits of Santa Ines pure lambs and crosses with Dorper finished in feedlot. Rev Bras Saúde Prod Anim. 2017;18(2):388-401. http://dx.doi.org/10.1590/s1519-99402017000200017.

Cattani M, Maccarana L, Rossi G, Tagliapietra F, Schiavon S, Bailoni L. Dose-response and inclusion effects of pure natural extracts and synthetic compounds on in vitro methane production. Anim Feed Sci Technol. 2016;218:100-9. http:// dx.doi.org/10.1016/j.anifeedsci.2016.05.014.

Chaves AV, Stanford K, Dugan MER, Gibson LL, McAllister TA, Van Herk F, Benchaar C. Effects of cinnamaldehyde, garlic and juniper berry essential oils on rumen fermentation, blood metabolites, growth performance, and carcass characteristics of growing lambs. Livest Sci. 2008;117(2/3):215-24. http:// dx.doi.org/10.1016/j.livsci.2007.12.013.

Cobellis G, Trabaliza-Marinucci M, Marcotullio MC, Yu Z. Evaluation of different essential oils in modulating methane and ammonia production, rumen fermentation and rumen bacteria in vitro. Anim Feed Sci Technol. 2016;215:25-36. http://dx.doi.org/10.1016/j.anifeedsci.2016.02.008.

Cowan MM. Plant products as antimicrobial agents. Clin Microbiol Rev. 1999;12(4):564-82. http://dx.doi.org/10.1128/ CMR.12.4.564. PMid:10515903.

Del Valle TA, Paiva PG, De Jesus EF, Almeida GF, Zanferari F, Costa AGBVB, Bueno ICS, Renno FP. Dietary chitosan improves nitrogen use and feed conversion in diets for midlactation dairy cows. Livest Sci. 2017;201:22-9. http://dx.doi. org/10.1016/j.livsci.2017.04.003.

Dorman HJD, Deans SG. Antimicrobial agents from plants: antibacterial activity of plant volatile oils. J Appl Microbiol. 2000;88(2):308-16. http://dx.doi.org/10.1046/j.13652672.2000.00969.x. PMid:10736000.

Droke EA, Spears JW, Armstrong JD, Kegley EB. Effect of feeding monensin on mineral metabolism in lambs unadapted and adapted to monensin (Abs). J Anim Sci. 1989;67(1):567.

Estell RE, Fredrickson EL, Anderson DM, Remmenga MD. Effects of cis- $\beta$-ocimene, cis-sabinene hydrate, and monoterpene and sesquiterpene mixtures on alfalfa pellet intake by lambs. J Anim Sci. 2008;86(6):1478-84. http:// dx.doi.org/10.2527/jas.2007-0699. PMid:18272857.

Estell RE, Fredrickson EL, Tellez MR, Havstad KM, Shupe WL, Anderson DM, Remmenga MD. Effects of volatile compounds on consumption of alfafa pellets by sheep. J Anim Sci. 1998;76(1):228-33. http://dx.doi.org/10.2527/1998.761228x. PMid:9464903.

Faleiro Neto JA. Impact of essential oils of Brazilian plants on ruminal parameters fermentation, digestibility and nitrogen balance in sheep [thesis]. São Paulo: School of Veterinary Medicine and Animal Sciences, Universidade de São Paulo; 2015. $150 \mathrm{p}$.

Gordon HM, Whitlock HV. A new technique for counting nematode eggs in sheep feces. J Counc Sci Ind Res. 1939;12:50-2.

Greene LW, May BJ, Schelling GT, Byers FM. Site and extent of apparent magnesium and calcium absorption in steers fed monensin. J Anim Sci. 1988;66(11):2987-91. http://dx.doi. org/10.2527/jas1988.66112987x. PMid:3225249.

Guerrero A, Valero MV, Campo MM, Sañudo C. Some factors that affect ruminant meat quality: from the farm to the fork. Acta Sci., Anim Sci. 2013;35(4):335-47. http:// dx.doi.org/10.4025/actascianimsci.v35i4.21756. 
Johann S, Sá NP, Lima LARS, Cisalpino PS, Cota BB, Alves TMA, Siqueira EP, Zani CL. Antifungal activity of schinol and a new biphenyl compound isolated from Schinus terebinthifolius against the pathogenic fungus Paracoccidioides brasiliensis. Ann Clin Microbiol Antimicrob. 2010;9(1):1-6. http://dx.doi.org/10.1186/1476-0711-9-30. PMid:20939907.

Kirk DJ, Greene LW, Schelling GT, Byers FM. Effects of monensin on $\mathrm{Mg}, \mathrm{Ca}, \mathrm{P}$ and $\mathrm{Zn}$ metabolism and tissue concentrations in lambs. J Anim Sci. 1985;60(6):1485-90. http://dx.doi.org/10.2527/jas1985.6061485x. PMid:4019342.

Lima MRF, Luna JS, Santos AF, Andrade MCC, Sant'Ana AEG, Genet JP, Marquez B, Neuville L, Moreau N. Anti-bacterial activity of some Brazilian medicinal plants. J Ethnopharmacol. 2006;105(1-2):137-47. https://doi.org/10.1016/j.jep.2005.10.026.

McIntosh FM, Williams P, Losa R, Wallace RJ, Beever DA, Newbold CJ. Effects of essential oils on ruminal microorganisms and their protein metabolism. Appl Environ Microbiol. 2003;60(8):5011-4. http://dx.doi.org/10.1128/AEM.69.8.50115014.2003. PMid:12902303.

Meyer NF, Erickson GE, Klopfenstein TJ, Greenquist MA, Luebbe MK, Williams P, Engstrom MA. Effects of essential oils, tylosin, and monensin on finishing steer performance, carcass characteristics, liver abscesses, ruminal fermentation, and digestibility. J Anim Sci. 2009;87(7):2346-54. http:// dx.doi.org/10.2527/jas.2008-1493. PMid:19359504.

Müller L. Typing of bovine carcasses. In: Anais da $28^{\mathrm{a}}$ Reunião Anual da Sociedade Brasileira de Zootecnia; 1991; João Pessoa. João Pessoa: SBZ; 1991. p. 3-11.

NRC: National Research Council. Nutrient requirements of small ruminants: Sheep, goats, cervids, and new world camelids. Washington: National Academy Press; 2007. 384 p.

Nicodemo MLF. Uso de aditivos na dieta de bovinos de corte. Campo Grande: EMBRAPA Gado de Corte; 2001.

Osório JCS, Osório MTM. Sistemas de avaliação de carcaças no Brasil. In: Anais do $1^{\circ}$ Simpósio Mineiro de Ovinocultura: produção de carne no contexto atual; 2001; Lavras, MG. Lavras (MG): UFLA; 2001. p. 157-96.

Perna F Jr, Cassiano ECO, Martins MF, Romero LA, Zapata DCV, Pinedo LA, Marino CT, Rodrigues PHM. Effect of tannins-rich extract from Acacia mearnsii or monensin as feed additives on ruminal fermentation efficiency in cattle. Livest Sci. 2017;203:21-9. http://dx.doi.org/10.1016/j. livsci.2017.06.009.

Petrovic MP, Petrovic VC, Ruzic-Muslic D, Maksimovic N, Petrovic MM, Ilic Z, Stojkovic J. Effect of genetic and environmental factors on the phenotype characteristics of lambs. Biotechnol Anim Husb. 2015;31(2):223-33. http:// dx.doi.org/10.2298/BAH1502223P.

Silva MA, Pessotti BMS, Zanini SF, Colnago GL, Nunes LC, Rodrigues MRA, Ferreira L. Brazilian red pepper oil on the performance and intestinal morphometry of broilers. Cienc Rural. 2010;40(10):2151-6. http://dx.doi.org/10.1590/S010384782010005000160 .

Spears JW, Schricker BR, Burns JC. Influence of lysocellin and monensin on mineral metabolism of steers fed foragebased diets. J Anim Sci. 1989;67(8):2140-149. http://dx.doi. org/10.2527/jas1989.6782140x. PMid:2793627.

Spears JW. Ionophores and nutrient digestion and absorption in ruminants. J Nutr. 1990;120(6):632-8. http://dx.doi. org/10.1093/jn/120.6.632. PMid:2191094.

Starnes SR, Spears JW, Froetschel MA, Croom WJ. Influence of monensin and lasalocid on mineral metabolism and ruminal urease activity in steers. J Nutr. 1984;114(3):518-25. https://doi.org/10.1093/jn/114.3.518.

Van Soest PJ, Robertson JB, Lewis BA. Symposium: carbohydrate methodology, metabolism, and nutritional implications in dairy cattle: methods for dietary fiber, neutral detergent fiber, and non-starch polysaccharides in relation to animal nutrition. J Dairy Sci. 1991;74:3583-97. http://dx.doi.org/10.3168/jds. S0022-0302(91)78551-2. PMid:1660498.

Weiss WP, Conrad HR, St Pierre NR. A theoretically-based model for predicting total digestible nutrient values of forages and concentrates. Anim Feed Sci Technol. 1992;39:95-110. http://dx.doi.org/10.1016/0377-8401(92)90034-4.

Financial Support: There was no funding agency

Authors Contributions: Conceptualization: Daniel Montanher Polizel; Alexandre Vaz Pires; Evandro Maia Ferreira; Marcos Vinícius de Castro Ferraz Júnior. Data acquisition: Analisa Vasques Bertoloni; Gabriela Bagio Oliveira; Alexandre Arantes Miszura; José Paulo Roman Barroso. Data analysis: Analisa Vasques Bertoloni; Gabriela Bagio Oliveira. Design of Methodology: Daniel Montanher Polizel; Alexandre Vaz Pires; Evandro Maia Ferreira; Marcos Vinícius de Castro Ferraz Júnior. Writing and editing: Analisa Vasques Bertoloni; Daniel Montanher Polizel; Arnaldo Cintra Limede; Arnaldo Cintra Limede; Lairana Aline Sardinha; André Storti Martins; Evandro Maia Ferreira; Alexandre Vaz Pires. 